Article

\title{
Highly Efficient Synthesis of 2,5-Dihydroxypyridine using Pseudomonas sp. ZZ-5 Nicotine Hydroxylase Immobilized on Immobead 150
}

\author{
Caiwen Dong ${ }^{1,2,3}$, Yadong Zheng ${ }^{1}$, Hongzhi Tang ${ }^{4}$, Zhangde Long ${ }^{5}$, Jigang $\mathrm{Li}^{5}$, \\ Zhiping Zhang ${ }^{1,2,3}$, Sumeng Liu ${ }^{1}$, Duobin Mao ${ }^{1,2,3, *}$ and Tao Wei ${ }^{1,2,3, *}$ \\ 1 School of Food and Biological Engineering, Zhengzhou University of Light Industry, Zhengzhou 450002, \\ China; biodcw@vip.126.com (C.D.); Zhengyd@163.com (Y.Z.); phosphor007@126.com (Z.Z.); \\ Liusm@126.com (S.L.) \\ 2 Collaborative Innovation Center of Food Production and Safety, Zhengzhou 450002, China \\ 3 Henan Key Laboratory of Cold Chain Food Quality and Safety Control, Zhengzhou 450002, China \\ 4 State Key Laboratory of Microbial Metabolism, School of Life Sciences and Biotechnology, Shanghai Jiao \\ Tong University, Shanghai 200240, China; Tanghz@126.com \\ 5 China Tobacco Guangxi Industrial Co., Ltd., Nanning 530001, China; Longzd@163.com (Z.L.); \\ ljg110916@sina.com (J.L.) \\ * Correspondence: duobinmao@126.com (D.M.); Weit8008@zzuli.edu.cn (T.W.); \\ Tel./Fax: +86-371-6355-6020 (D.M.); +86-371-8660-9631 (T.W.)
}

Received: 30 September 2018; Accepted: 13 November 2018; Published: 16 November 2018

\begin{abstract}
In this report, the use of immobilized nicotine hydroxylase from Pseudomonas sp. ZZ-5 $\left(\mathrm{HSPH}_{\mathrm{ZZ}}\right)$ for the production of 2,5-dihydroxypyridine (2,5-DHP) from 6-hydroxy-3succinoylpyridine (HSP) in the presence of nicotinamide adenine dinucleotide (NADH) and flavin adenine dinucleotide (FAD) is described. $\mathrm{HSPH}_{\mathrm{ZZ}}$ was covalently immobilized on Immobead 150 (ImmHSPH $\mathrm{ZZ}_{\mathrm{Z}}$ ). ImmHSPH $\mathrm{ZZ}$ (obtained with 5-30 mg of protein per gram of support) catalyzed the hydrolysis of HSP to 2,5-DHP. At a protein loading of $15 \mathrm{mg} \mathrm{g}^{-1}$, ImmHSPH $_{\mathrm{ZZ}}$ converted $93.6 \%$ of HSP to 2,5-DHP in $6 \mathrm{~h}$. The activity of ImmHSPHzZ was compared with that of free $\mathrm{HSPH}_{\mathrm{ZZ}}$ under various conditions, including $\mathrm{pH}$, temperature, enzyme concentration, substrate concentration and stability over time, and kinetic parameters were measured. The results showed that $\mathrm{ImmHSPH}_{Z Z}$ performed better over wider ranges of $\mathrm{pH}$ and temperature when compared with that of $\mathrm{HSPH}_{\mathrm{ZZ}}$. The optimal concentrations of $\mathrm{ImmHSPH}_{\mathrm{ZZ}}$ and substrate were $30 \mathrm{mg} \mathrm{L}^{-1}$ and $0.75 \mathrm{mM}$, respectively. Under optimal conditions, $94.5 \mathrm{mg} \mathrm{L}^{-1}$ of 2,5-DHP was produced after $30 \mathrm{~min}$ with $85.4 \%$ conversion. After 8 reaction cycles and 6 days of storage, $51.3 \%$ and $75.0 \%$ of the initial enzyme activity remained, respectively. The results provide a framework for development of commercially suitable immobilized enzymes that produce 2,5-DHP.
\end{abstract}

Keywords: 2,5-DHP; immobilization; $\mathrm{HSPH}_{\mathrm{ZZ}}$; ImmHSPH $\mathrm{ImZ}_{\mathrm{Z}}$; hydrolytic activity

\section{Introduction}

Nicotine is a major pyridine alkaloid found in tobacco that causes smoking addiction and several diseases such as pulmonary disease and cancer [1,2]. The manufacturing of tobacco products produces large amounts of toxic solid, liquid and airborne waste with high nicotine content $[3,4]$. Nicotine is very toxic to human health and the disposal of tobacco waste is a serious ecological problem [5,6]. As an environmentally friendly treatment, microbial degradation of nicotine is a promising approach because of its low cost and high efficiency. Several microorganisms including Arthrobacter species, Pseudomonas species, Agrobacterium tumefaciens S33, Ochrobactrum intermedium, Aspergillus oryzae, 
Rhodococcus species, Agrobacterium species and Sphingomonas species have been reported to degrade nicotine [7-15]. Pyridine derivatives from nicotine are used extensively in functional materials and found in natural products that possess important biological activities. Recent studies have reported that several intermediates produced from nicotine degradation by microorganisms are important precursors (e.g., 2,5-dihydroxy-pyridine (2,5-DHP)) [5,16]. In addition, the drug 5-aminolevulinic acid, used in cancer therapy, has been produced from degradation of nicotine by microorganisms [17].

Immobilization of enzymes is an essential facet of modern biotechnology. Enzyme immobilization (especially on magnetic carriers) offers many advantages when compared with soluble enzyme preparations, including the ability to improve the catalytic properties of the enzyme, easy enzyme recovery and reuse, and reduced catalytic processing costs [18-20]. Various methods, including physical adsorption, covalent binding, cross-linking, entrapment and encapsulation, have been used for enzyme immobilization. Among them, the covalent binding method could make it difficult for the free enzyme to leach and exhibit high enzymatic activity due to the strong interaction between the enzyme and carrier function group [21-23].

In our previous work, the synthesis of 2,5-DHP from 6-hydroxy-3-succinoylpyridine (HSP) using HSP (6-hydroxy-3-succinoylpyridine) hydroxylase from Pseudomonas sp. ZZ-5 (HSPHzZ) was attempted, and the yield of 2,5-DHP reached $74.9 \%(w / w)$ in 40 min under optimal conditions [24]. However, recovery and reuse of $\mathrm{HSPH}_{\mathrm{ZZ}}$ could not be achieved. Therefore, to improve the catalytic properties and reduce the cost of the biocatalytic process, $\mathrm{HSPH}_{\mathrm{ZZ}}$ should be immobilized. Until now, there are no published reports on the synthesis of 2,5-DHP by immobilized HSP hydroxylase. In this context, the aim of this work was to optimize the synthesis of 2,5-DHP catalyzed by $\mathrm{HSPH}_{\mathrm{ZZ}}$ covalently immobilized on Immobead $150\left(\mathrm{ImmHSPH}_{\mathrm{ZZ}}\right)$ by determining the optimal $\mathrm{pH}$, temperature, and enzyme and substrate concentrations. Kinetic parameters $K_{\mathrm{m}}$ and $k_{\text {cat }}$ were determined and reusability was also examined.

\section{Results and Discussion}

\subsection{Immobilization of Purified HSPHZZ on Immobead 150}

The immobilization of $\mathrm{HSPH}_{Z Z}$ was performed with Immobead 150, and the immobilized $\mathrm{HSPH}_{\mathrm{ZZ}}$ was termed ImmHSPH $\mathrm{ZZ}_{\mathrm{ZZ}}$. Protein loadings and immobilization times were $5-30 \mathrm{mg} \mathrm{g}^{-1}$ and $6 \mathrm{~h}$, respectively. Table 1 shows that the immobilization efficiency of $\mathrm{HSPH}_{\mathrm{ZZ}}$ was $100 \%$ when the $\mathrm{HSPH}_{\mathrm{ZZ}}$ loading ranged from $5 \mathrm{mg} \mathrm{g}^{-1}$ to $20 \mathrm{mg} \mathrm{g}^{-1}$. This result indicated that the support of Immobead 150 was not saturated at the high $\mathrm{HSPH}_{Z Z}$ loading. The immobilization efficiency decreased to $45 \%$ when the $\mathrm{HSPH}_{Z Z}$ loading increased to $30 \mathrm{mg} \mathrm{g}^{-1}$. The retention of activity increased with increasing $\mathrm{HSPH}_{\mathrm{ZZ}}$ loading (5-15 mg g ${ }^{-1}$ ). The highest retention of activity of $\mathrm{ImmHSPH}_{\mathrm{ZZ}}$ was achieved (95\%) at a $\mathrm{HSPH}_{\mathrm{ZZ}}$ loading of $15 \mathrm{mg} \mathrm{g}^{-1}$. The retention of activity decreased to $45 \%$ when $\mathrm{HSPH}_{Z Z}$ loading was further increased from 20 to $30 \mathrm{mg} \mathrm{g}^{-1}$. The preparation of $\mathrm{HSPH}_{Z Z}$ immobilized on Immobead 150 was used to catalyze the hydrolysis of HSP to 2,5-DHP with $\mathrm{HSPH}_{Z Z}$ loadings of $5,10,15$ and $20 \mathrm{mg} \mathrm{g}^{-1}$ (Figure 1). The reaction products catalyzed by $\mathrm{ImmHSPH}_{\mathrm{ZZ}}$ were identified using liquid chromatography-mass spectrometry (LC-MS. The reaction time was $6 \mathrm{~h}$, and the yields of 2,5-DHP were $85.1 \%, 92.7 \%, 93.6 \%$ and $82.6 \%$ at $\mathrm{HSPH}_{\mathrm{ZZ}}$ loadings of 5, 10, 15 and $20 \mathrm{mg} \mathrm{g}^{-1}$, respectively. These results demonstrated that the immobilized $\mathrm{HSPH}_{\mathrm{ZZ}}$ showed high hydroxylase activity after covalent binding to Immobead 150.

\subsection{Scanning Electron Microscopy (SEM) Analysis of $\mathrm{HSPH}_{Z Z}$ and ImmHSPHZZ}

The surface structure of $\mathrm{HSPH}_{\mathrm{ZZ}}$ before and after covalently immobilizing on Immobead 150 was observed using SEM (Figure 2). The hydroxylase bound to the surface of the beads and the surface morphology of $\mathrm{HSPH}_{\mathrm{ZZ}}$ immobilized to the beads differed when compared with that of the free enzyme. The ImmHSPH $\mathrm{IZ}_{\mathrm{ZZ}}$ surface became spheroid in shape after immobilization, which may be caused by the formed covalent bond between an amino group located on the surface of the enzyme and 
the support matrix oxirane ring of Immobead 150 [25]. Therefore, these results showed that nicotine hydroxylase $\mathrm{HSPH}_{Z Z}$ was immobilized on Immobead 150.

Table 1. Effect of the protein to support ratio (protein loading) on the immobilization of purified HSPHZZ on Immobead 150.

\begin{tabular}{cccc}
\hline - & $\begin{array}{c}\text { Protein Loading } \\
\text { (mg g-1) }\end{array}$ & $\begin{array}{c}\text { Immobilization } \\
\text { Efficiency (IE) (\%) }\end{array}$ & $\begin{array}{c}\text { Retention of } \\
\text { Activity (R) (\%) }\end{array}$ \\
\hline Immobead 150 & 5 & 100 & 78 \\
- & 10 & 100 & 85 \\
- & 15 & 100 & 95 \\
- & 20 & 100 & 75 \\
- & 25 & 90 & 51 \\
\hline
\end{tabular}

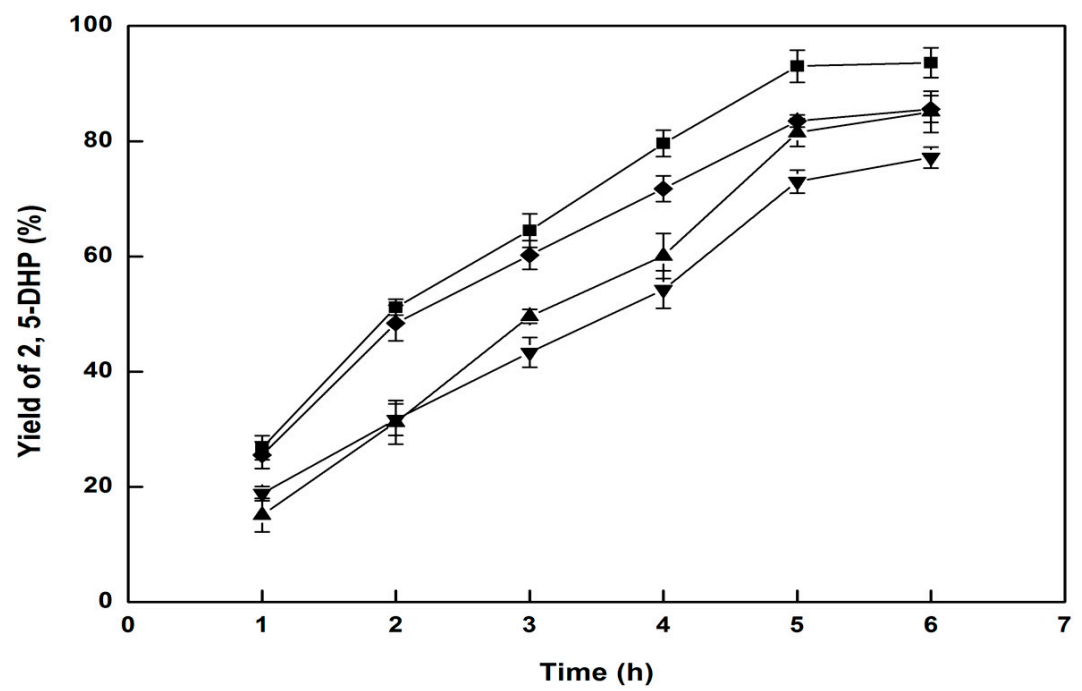

Figure 1. Synthesis of 2,5-dihydroxypyridine (2,5-DHP) by Immobead 150 (ImmHSPHzz) at protein loading of $(\boldsymbol{\Delta}) 5,(\boldsymbol{\vee}) 10,(\boldsymbol{\square}) 15$ and $(\boldsymbol{\nabla}) 20 \mathrm{mg} \mathrm{g}^{-1}$. The reactions were performed in $20 \mathrm{mM}$ Tris- $\mathrm{HCl}$ buffer (pH 9.0) containing $0.75 \mathrm{mM} \mathrm{HSP}, 30 \mathrm{mg} / \mathrm{mL} \mathrm{ImmHSPH}_{\mathrm{ZZ}}, 10 \mathrm{mM}$ FAD and $0.5 \mathrm{mM} \mathrm{NADH}$ at $35{ }^{\circ} \mathrm{C}$ for $30 \mathrm{~min}$.

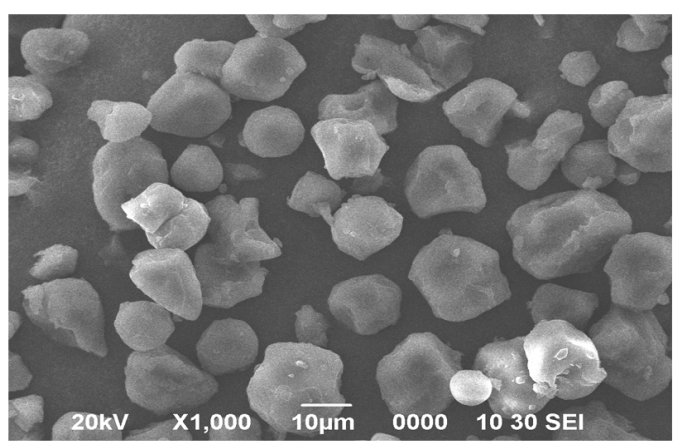

a

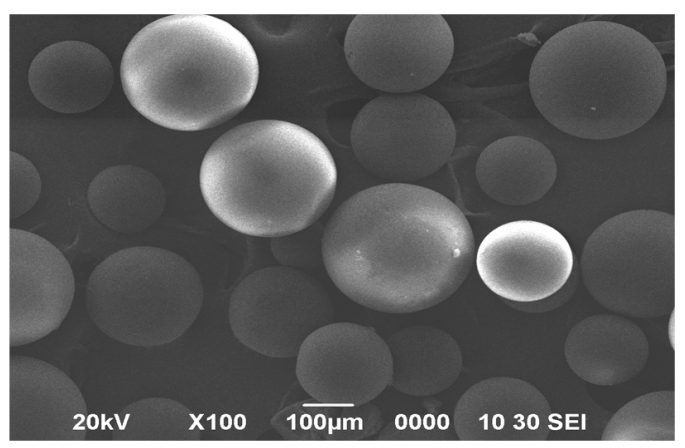

b

Figure 2. SEM micrographs of surface of $\mathrm{HSPH}_{\mathrm{ZZ}}$ (a) and $\operatorname{ImmHSPH}_{\mathrm{ZZ}}$ (b). Magnification: (a) $\times 1000$; (b) $\times 100$. 


\subsection{Effect of $\mathrm{pH}$ on the Activity of $\mathrm{HSPH}_{\mathrm{ZZ}}$ and $\mathrm{ImmHSPH}_{\mathrm{ZZ}}$}

The effect of $\mathrm{pH}$ on the hydrolytic activity of $\mathrm{HSPH}_{\mathrm{ZZ}}$ and $\mathrm{ImmHSPH}_{\mathrm{ZZ}}$ was investigated at $\mathrm{pH}$ values between 5.0 and 10.0. As shown in Figure 3, free $\mathrm{HSPH}_{\mathrm{ZZ}}$ showed higher hydrolytic activities over the $\mathrm{pH}$ range of 8.0-9.0 with a maximum activity at $\mathrm{pH}$ 8.5. After immobilization on Immobead 150, the optimum $\mathrm{pH}$ range was between 7.5 and 9.5, and maximal activity was observed at $\mathrm{pH} 9.0$, indicating that the immobilized $\mathrm{HSPH}_{\mathrm{ZZ}}$ exhibited higher tolerance to alkaline $\mathrm{pHs}$. $\mathrm{ImmHSPH}_{\mathrm{ZZ}}$ maintained over $50 \%$ of its maximum activity at $\mathrm{pH} 7.0-10.0$, whereas the free $\mathrm{HSPH}_{\mathrm{ZZ}}$ maintained over $50 \%$ of its maximum activity at $\mathrm{pH}$ 7.0-9.0. These observations showed that immobilization of HSPHzz improved enzymatic performance over a wider $\mathrm{pH}$ range. This improved $\mathrm{pH}$-stability may be because of the covalent bond formed and possible secondary interactions between the enzyme and the functional groups of the carrier, which enhance the stability of the molecular structure of the immobilized enzyme at various $\mathrm{pH}$ values [26]. This behavior could be explained by influence of the partition effects on the enzymatic activities of the immobilized protein, which were from different concentrations of charged species in the micro-environment of the immobilized protein and reaction solution [27].

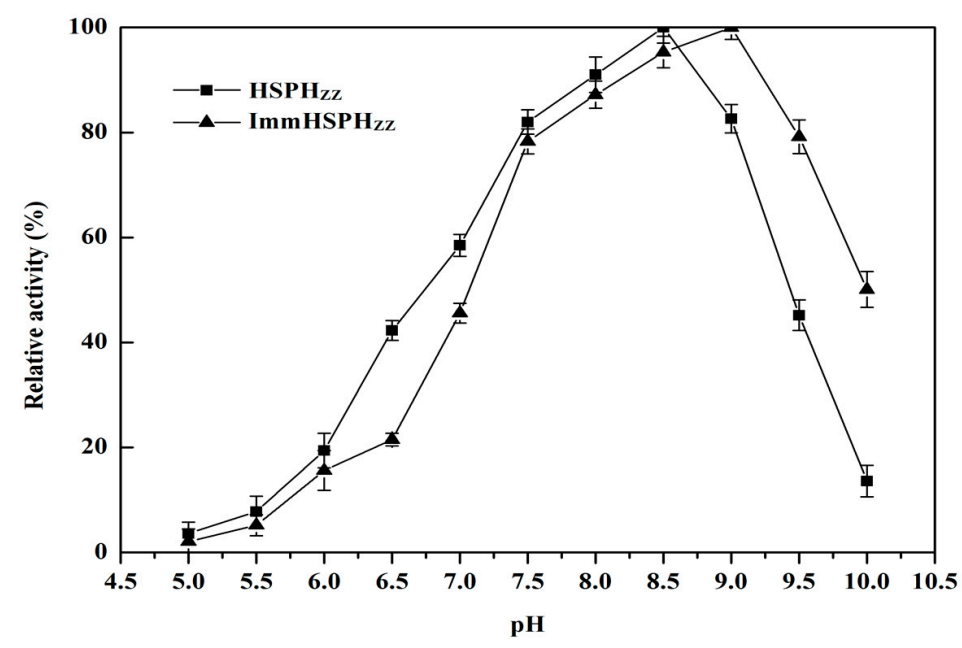

Figure 3. Temperature optima of $\mathrm{HSPH}_{\mathrm{ZZ}}$ and $\mathrm{ImmHSPH}_{\mathrm{ZZ}}$. The buffers $(20 \mathrm{mM})$ used: sodium acetate ( $\mathrm{pH}$ 5.5-6.0), sodium phosphate $(\mathrm{pH}$ 6.5-7.5), Tris- $\mathrm{HCl}(\mathrm{pH}$ 8.0-9.0) and N-cyclohexyl-3aminopropanesulfonic acid (pH 9.5-10.0).

\subsection{Effect of Temperature on the Activity of $\mathrm{HSPH}_{\mathrm{ZZ}}$ and $\mathrm{ImmHSPH}_{\mathrm{ZZ}}$}

The effect of temperature on the hydrolytic activity of $\mathrm{HSPH}_{Z Z}$ and $\mathrm{ImmHSPH}_{Z Z}$ was evaluated. Immobilization of $\mathrm{HSPH}_{Z Z}$ strongly increased its thermostability when compared with that of the free $\mathrm{HSPH}_{\mathrm{ZZ}}$ (Figure 4). Maximal activity of ImmHSPH $\mathrm{ZZ}_{\mathrm{ZZ}}$ was observed at $\sim 35^{\circ} \mathrm{C}$ and more than half the maximal activity was observed at $15-45^{\circ} \mathrm{C}$. In contrast, the maximal activity of $\mathrm{HSPH}_{\mathrm{ZZ}}$ was $\sim 30{ }^{\circ} \mathrm{C}$, and more than half the maximal activity was observed at $20-35^{\circ} \mathrm{C}$. Thermal stabilities of $\mathrm{HSPH}_{\mathrm{ZZ}}$ and ImmHSPH $\mathrm{ZZ}_{\mathrm{ZZ}}$ were investigated at $40^{\circ} \mathrm{C}$ with increasing incubation periods up to 6 days. After incubation for 6 days, the enzymatic activity of ImmHSPH$_{Z Z}$ was only partly reduced $(\sim 73 \%)$, whereas the activity of $\mathrm{HSPH}_{Z Z}$ had reduced to $13 \%$. Thus, temperature has a lower impact on the activity profile of $\mathrm{ImmHSPH}_{\mathrm{ZZ}}$ when compared with that of $\mathrm{HSPH}_{\mathrm{ZZ}}$. This result demonstrated that the immobilized $\mathrm{HSPH}_{Z Z}$ showed higher thermostability than the free enzyme $[25,26]$. The thermostability of the immobilized $\mathrm{HSPH}_{\mathrm{ZZ}}$ is in accordance with that of other previously reported immobilized enzymes. This improved thermostability may be because of the formation of the covalent linkage between $\mathrm{HSPH}_{\mathrm{ZZ}}$ and Immobead 150, which changes the conformation of the enzyme as a result of the temperature changes [27]. 


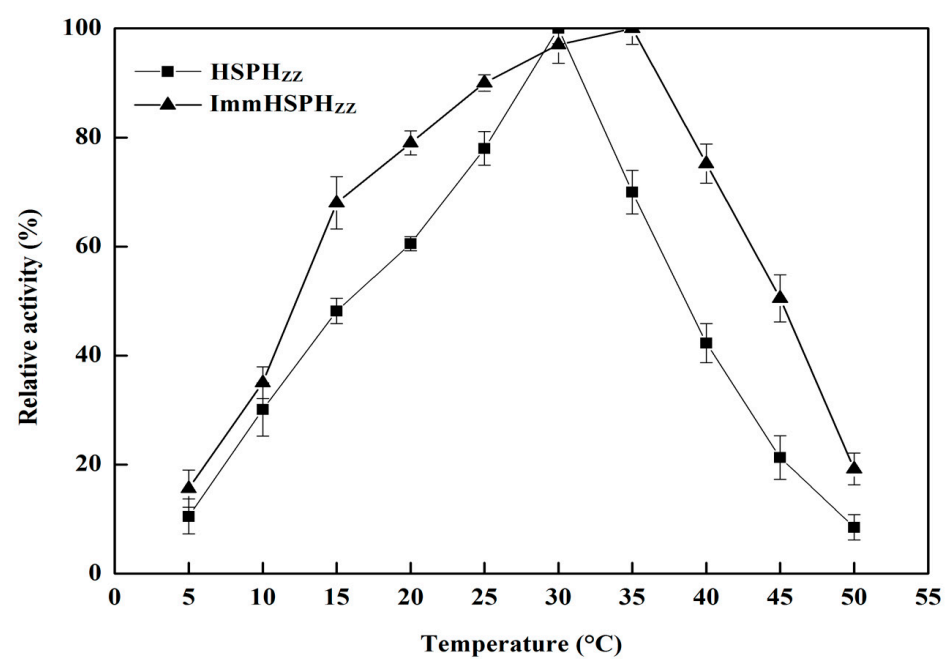

$\mathrm{a}$

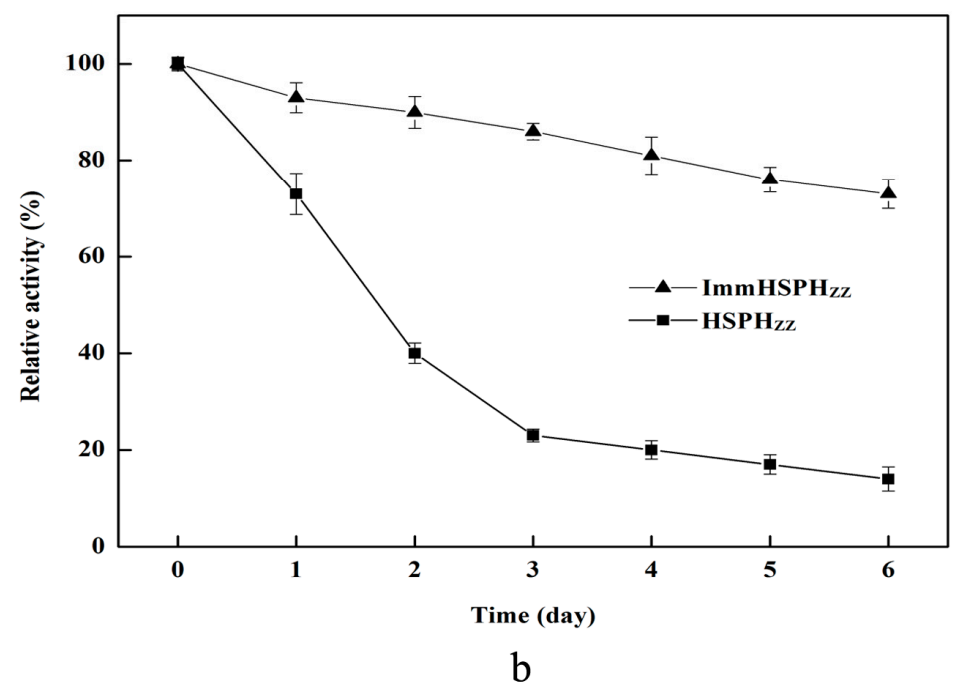

Figure 4. Temperature optima (a) and thermostability (b) of $\mathrm{HSPH}_{\mathrm{ZZ}}$ and $\mathrm{ImmHSPH}_{\mathrm{ZZ}}$. (a) Temperature optimums of $\mathrm{HSPH}_{Z Z}$ and $\mathrm{ImmHSPH}_{\mathrm{ZZ}}$ were determined with $\mathrm{HSP}$ as substrate in $20 \mathrm{mM}$ Tris- $\mathrm{HCl}$ buffer ( $\mathrm{pH}$ 9.0) at temperatures ranging from 5 to $50{ }^{\circ} \mathrm{C}$. (b) Thermostability of $\mathrm{HSPH}_{\mathrm{ZZ}}$ and $\mathrm{ImmHSPH}_{\mathrm{ZZ}}$. The residual enzyme activity was measured after incubation of the enzyme at $40{ }^{\circ} \mathrm{C}$.

\subsection{Effect of Enzymatic Concentration on the Activity of ImmHSPHZZ}

Different enzymatic concentrations $\left(10-50 \mathrm{mg} \mathrm{mL}^{-1}\right)$ were studied to determine the optimal conditions for synthesis of 2,5-DHP. Interestingly, a lower yield of 2,5-DHP was obtained at higher concentrations of ImmHSPH IZ $_{\text {( }} 40-50 \mathrm{mg} \mathrm{mL}^{-1}$; Figure 5). The highest 2,5-DHP yield (95.6\%) was obtained at an enzyme concentration of $30 \mathrm{mg} \mathrm{mL}^{-1}$. In general, the product yield increased as the concentration of the enzyme increased. However, the presence of excess catalyst $\left(>30 \mathrm{mg} \mathrm{mL}^{-1}\right)$ can result in enzyme agglomeration and diffusion problems, which can reduce reaction efficiency [28,29]. An ImmHSPH $\mathrm{ZZ}_{\mathrm{ZZ}}$ loading of $30 \mathrm{mg} \mathrm{mL}^{-1}$ offered the efficient hydrolysis of HSP and synthesis of 2,5-DHP. 


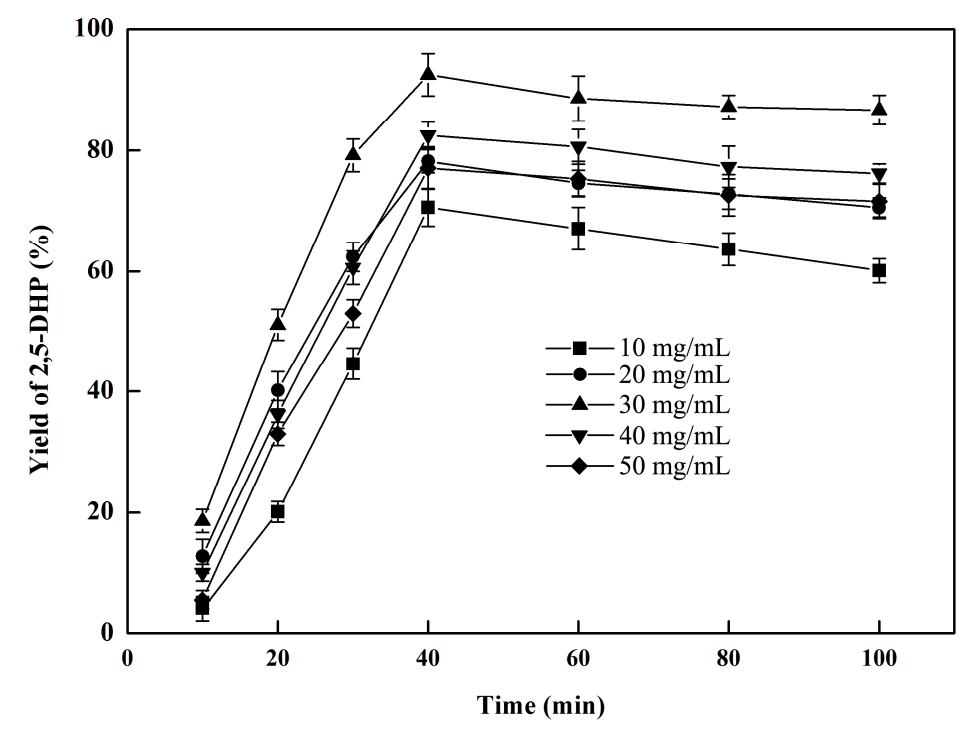

Figure 5. Effect of enzyme concentration of $\mathrm{ImmHSPH}_{\mathrm{ZZ}}$ on the production of 2,5-DHP.

\subsection{Effect of HSP Concentration on the Activity of ImmHSPH}

The yields of 2,5-DHP produced by ImmHSPH $\mathrm{ZZZ}_{\mathrm{ZZ}}$ at different HSP concentrations $(0.25-2.0 \mathrm{mM})$ are shown in Figure 6. The reaction rate increased with increasing HSP concentrations between 0.25 and $0.75 \mathrm{mM}$. The highest yield of 2,5-DHP was achieved at a HSP concentration of $0.75 \mathrm{mM}$. The yield of 2,5-DHP decreased when the HSP concentration was further increased from 1.0 to $2.0 \mathrm{mM}$. This may be because higher amounts of HSP limit substrate mass transfer to the active center of $\mathrm{ImmHSPH}_{Z Z}[30,31]$. The Michaelis-Menten equation was used for kinetic analysis of ImmHSPH $\mathrm{ZZ}_{\mathrm{ZZ}}$. The kinetic parameters of ImmHSPH $\mathrm{ZZ}_{\mathrm{ZZ}}$ for HSP were calculated under optimal conditions and at the NADH concentration of $1.0 \mathrm{mM}$. As shown in Table 2, the $k_{\text {cat }} / K_{\mathrm{m}}$ value of ImmHSPH $\mathrm{ZZ}\left(24.0 \mathrm{~S}^{-1} \mathrm{mM}^{-1}\right)$ toward HSP is higher than that of $\mathrm{HSPH}_{\mathrm{ZZ}}\left(10.6 \mathrm{~S}^{-1} \mathrm{mM}^{-1}\right)$. Moreover, the $k_{\text {cat }} / K_{\mathrm{m}}$ value of $\operatorname{ImmHSPH}_{\mathrm{ZZ}}\left(23.6 \mathrm{~S}^{-1} \mathrm{mM}^{-1}\right)$ toward NADH is higher than that of $\mathrm{HSPH}_{\mathrm{ZZ}}\left(8.3 \mathrm{~S}^{-1} \mathrm{mM}^{-1}\right)$. Kinetic parameters $\left(K_{\mathrm{m}}, k_{\text {cat }}\right.$ and $\left.K_{\text {cat }} / K_{m}\right)$ for immobilized enzymes often differ when compared with the corresponding parameters obtained for the free enzyme [32,33]. These results demonstrated that $\mathrm{ImmHSPH}_{Z Z}$ exhibited higher substrate affinity and catalytic efficiency when compared with that of $\mathrm{HSPH}_{\mathrm{ZZ}}$.

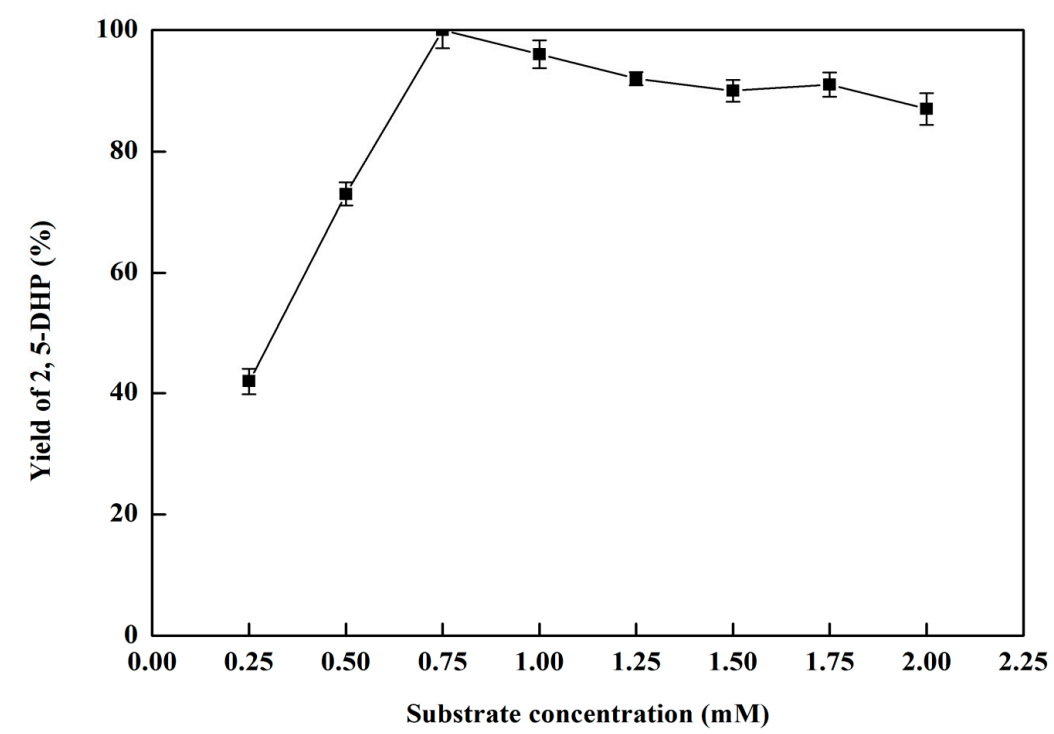

Figure 6. Effect of substrate concentration on the production of 2,5-DHP for $\mathrm{HSPH}_{\mathrm{ZZ}}$ and $\mathrm{ImmHSPH}_{\mathrm{ZZ}}$. 
Table 2. Kinetic parameters of HSPHZZ and ImmHSPHZZ for the substrate of HSP or DADH.

\begin{tabular}{ccccc}
\hline Protein & Substrate & $\boldsymbol{k}_{\text {cat }}\left(\mathbf{s}^{-\mathbf{1}}\right)$ & $\boldsymbol{K}_{\mathbf{m}}(\mathbf{m M})$ & $\boldsymbol{k}_{\text {cat }} / \boldsymbol{K}_{\mathbf{m}}\left(\mathbf{s}^{\mathbf{- 1}} \mathbf{m M}^{-\mathbf{1}}\right)$ \\
\hline HSPH $_{Z Z}$ & HSP & $1.9 \pm 0.3$ & $0.18 \pm 0.02$ & $10.6 \pm 2.1$ \\
- & NADH & $1.5 \pm 0.4$ & $0.18 \pm 0.04$ & $8.3 \pm 1.9$ \\
ImmHSPH ZZ $_{-}$ & HSP & $4.8 \pm 0.4$ & $0.20 \pm 0.02$ & $24.0 \pm 2.1$ \\
- & NADH & $5.2 \pm 0.2$ & $0.22 \pm 0.05$ & $23.6 \pm 1.9$ \\
\hline
\end{tabular}

\subsection{2,5-DHP Production from HSP by ImmHSPH $\mathrm{ZZ}$ under Optimum Conditions}

The production of 2,5-DHP from HSP by $\mathrm{ImmHSPH}_{\mathrm{ZZ}}$ was measured under optimal conditions (at $35{ }^{\circ} \mathrm{C}$ and $\mathrm{pH} 9.0$ in $20 \mathrm{mM}$ Tris- $\mathrm{HCl}$ buffer) with ImmHSPH $\mathrm{ZZZ}_{\mathrm{ZZ}}$ at a concentration of $30 \mathrm{mg}$ $\mathrm{mL}^{-1}$. The immobilized enzyme produced 2,5-DHP $\left(97.2 \mathrm{mg} \mathrm{L}^{-1}\right)$ at a conversion of $85.4 \%(w / w)$ after a reaction time of $30 \mathrm{~min}$ (Figure 7). In our previous work, the yield of 2,5-DHP using free $\mathrm{HSPH}_{\mathrm{ZZ}}$ reached $74.9 \%$ in 40 min under optimal conditions [24]. Therefore, the yield of 2,5-DHP catalyzed by ImmHSPH $\mathrm{ZZ}_{\mathrm{ZZ}}$ is higher when compared with that of $\mathrm{HSPH}_{\mathrm{ZZ}}$, and 2,5-DHP was produced in a shorter reaction time (30 $\mathrm{min}$ ) when HSP was catalyzed by $\mathrm{ImmHSPH}_{\mathrm{ZZ}}$. The production of 2,5-DHP from HSP by ImmHSPH $\mathrm{ZZ}_{\mathrm{Z}}$ was also higher than that of the nicotine HSP hydroxylase from A. tumefaciens S33 (a conversion of $69.7 \%$ in $50 \mathrm{~min}$ ) [10]. These results demonstrated that enzymatic transformation of HSP to 2,5-DHP by ImmHSPH ${ }_{Z Z}$ was superior to free $\mathrm{HSPH}_{\mathrm{ZZ}}$ and likely to be suitable for commercial applications.

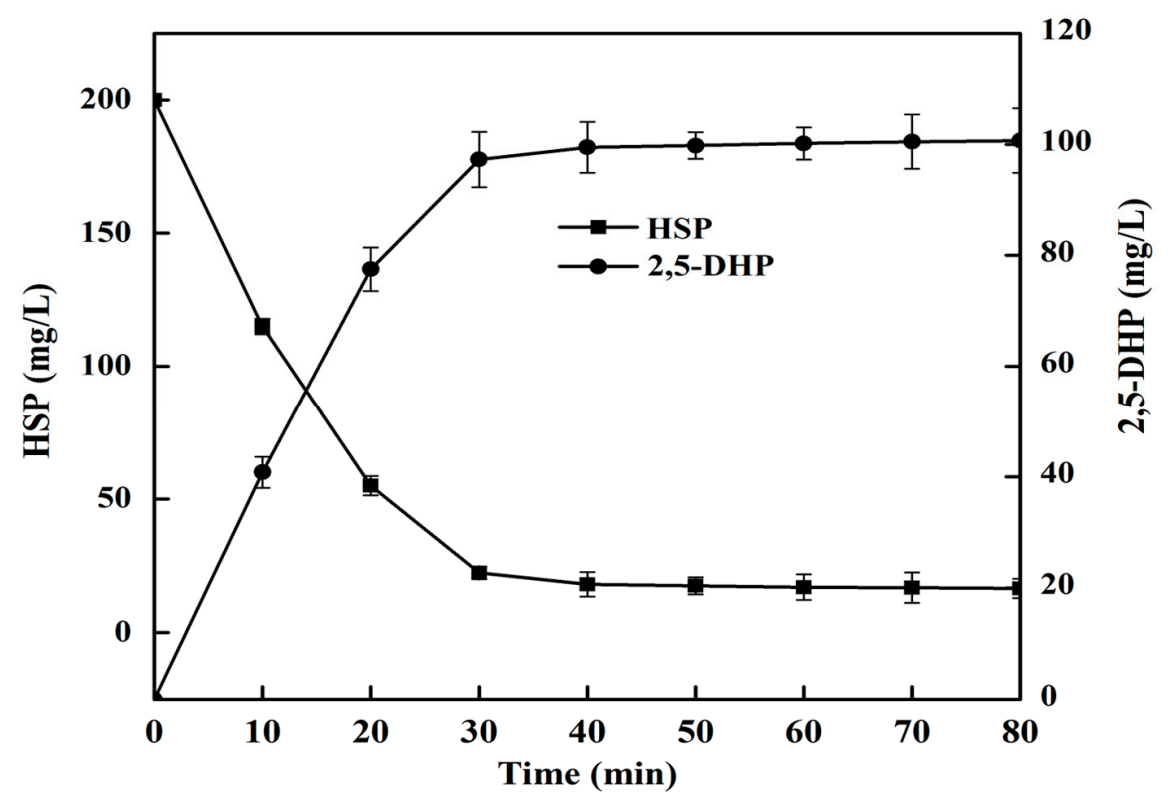

Figure 7. Time course of 2,5-DHP (circles) production from HSP (boxes) for ImmHSPHzZ under the optimum condition.

\subsection{Stability of Storage and Reusability}

The stability of storage and reusability is an important requirement for industrial enzyme applications. Immobilization of the enzyme may improve resistance to reaction conditions and conformational changes, which reduces the likelihood of denaturation $[34,35]$. The storage stability and operational stability of ImmHSPH $\mathrm{ZZ}_{\mathrm{ZZ}}$ towards HSP were evaluated (Figure 8). The results showed that the immobilized enzyme kept $51.3 \%$ of its activity up until eight cycles. These results may be explained that $\mathrm{HSPH}_{Z Z}$ release from the support during recycle use due to weak interaction between Immobead 150 and the enzyme. To investigate the storage stability of $\mathrm{ImmHSPH}_{Z Z}$, the activity of $\mathrm{HSPH}_{Z Z}$ after incubating the enzyme at $4{ }^{\circ} \mathrm{C}$ for different time intervals was measured. After 6 days, the relative activity of $\mathrm{ImmHSPH}_{\mathrm{ZZ}}$ remained greater than $75.0 \%$ of the initial activity, whereas that 
of $\mathrm{HSPH}_{\mathrm{ZZ}}$ was only $\sim 9 \%$ of the initial activity. These results indicated that the storage stability of $\mathrm{ImmHSPH}_{Z Z}$ was clearly superior when compared with that of $\mathrm{HSPH}_{\mathrm{ZZ}}$.

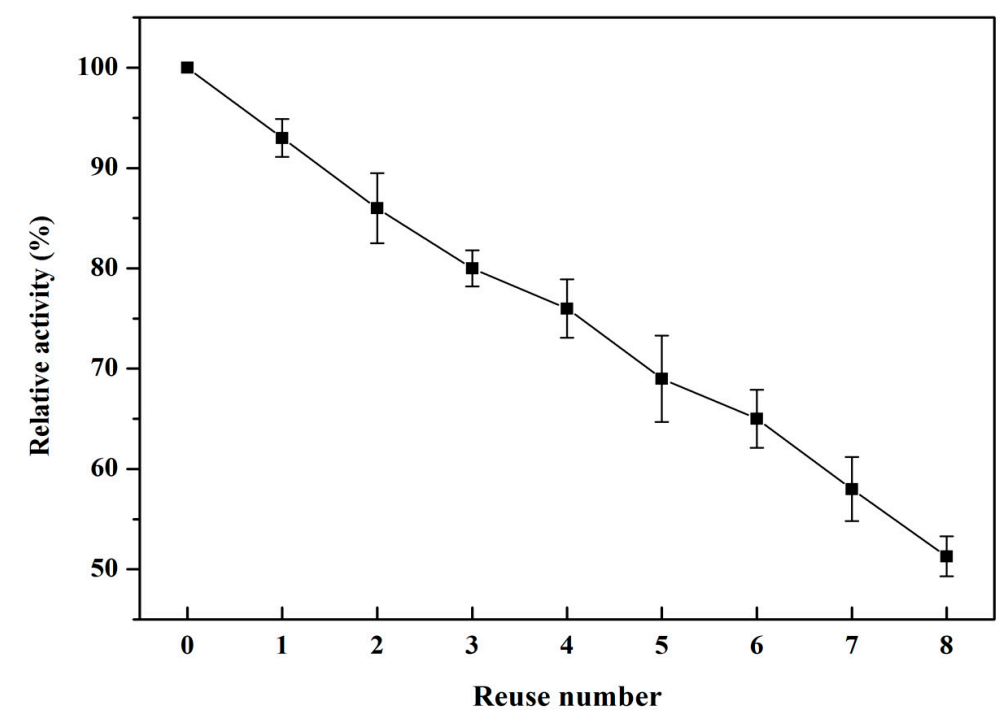

a

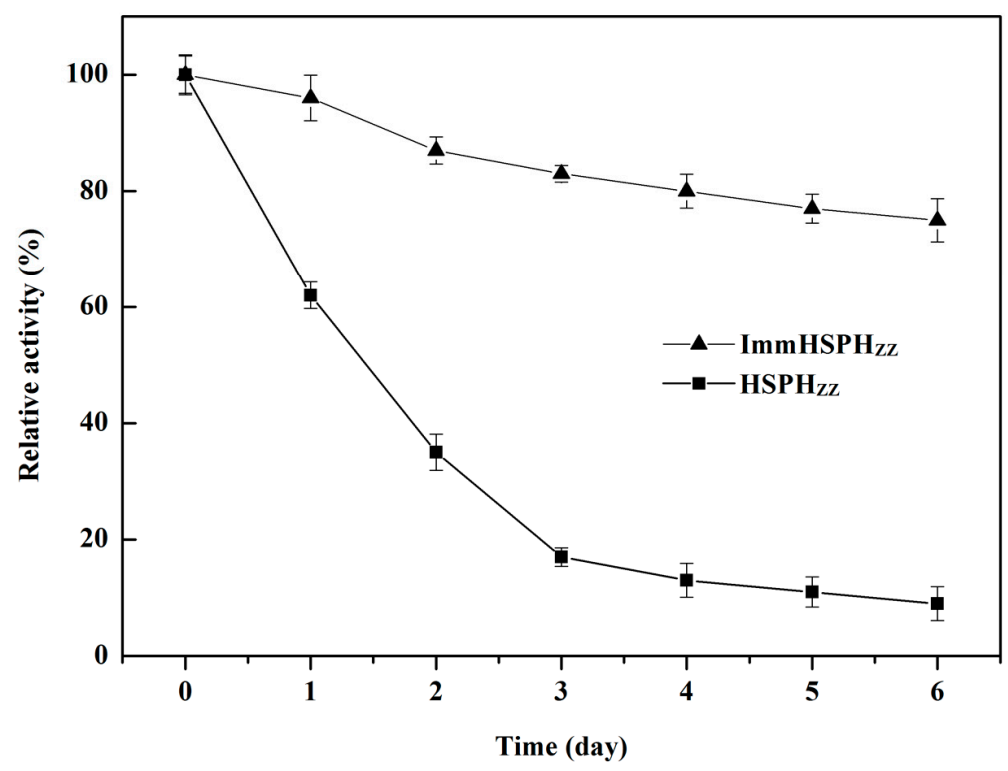

b

Figure 8. Stability of reusability (a) and storage (b) of immobilized ImmHSPHZZ.

\section{Materials and Methods}

\subsection{Materials}

2,5-DHP was purchased from SynChem OHG (Altenburg, Germany). The Immobead 150 support and succinic acid were purchased from Sigma Aldrich Co. (St. Louis, MO, USA). HSP was obtained from Professor Hongzhi Tang at Shanghai Jiao Tong University. All other chemicals used were analytical grade quality and obtained from commercial sources in China. 


\subsection{Multipoint Immobilization of $\mathrm{HSPH}_{\mathrm{ZZ}}$ on Immobead 150}

The support of Immobead $150(0.2 \mathrm{~g})$ was added to a $\mathrm{HSPH}_{\mathrm{ZZ}}$ solution $(5 \mathrm{~mL})$ in $20 \mathrm{mM}$ sodium bicarbonate buffer ( $\mathrm{pH} 8.5$ ), with $\mathrm{HSPH}_{\mathrm{ZZ}}$ loadings ranging from $5 \mathrm{mg} \mathrm{g}^{-1}$ to $30 \mathrm{mg} \mathrm{g}^{-1}$. The mixture was incubated at $4{ }^{\circ} \mathrm{C}$ for $6 \mathrm{~h}$ in an orbital shaker operating at $150 \times \mathrm{rpm}$. To check for covalent binding, the mixture was washed with $1 \mathrm{M} \mathrm{NaCl}$ and ethylene glycol $(30 \%, v / v)$, centrifuged, vacuum freeze-dried and stored at $10{ }^{\circ} \mathrm{C}$. The immobilization efficiency (IE, \%) and retention of activity ( $\left.\mathrm{R}, \%\right)$ were calculated according to Madalozzo et al. [36].

\subsection{Characterization of $\mathrm{HSPH}_{\mathrm{ZZ}}$ and $\mathrm{ImmHSPH}_{\mathrm{ZZ}}$}

The activity of $\mathrm{HSPH}_{\mathrm{zz}}$ and $\mathrm{ImmHSPH}_{\mathrm{ZZ}}$ hydroxylase was determined by the catalysis of HSP to 2,5-DHP, as described previously [24]. The production of 2,5-DHP was measured by an electron spray ionization (ESI) source on an AB Sciex Triple Quad 5500 mass spectrometer (AB Sciex, Framingham, MA, USA) with an Agilent 1290 infinity liquid chromatography (LC) system for ultra high performance liquid chromatography (UHPLC). The mobile phase was methanol/acetic acid $(v / v, 25: 75)$ at a flow rate of $0.5 \mathrm{~mL} \mathrm{~min}^{-1}$. One unit of $\mathrm{HSPH}_{\mathrm{ZZ}}$ and $\mathrm{ImmHSPH}_{\mathrm{ZZ}}$ were defined as the amount of enzyme required to synthesize $1 \mathrm{~mol} 2,5$-DHP per min under the standard conditions.

The activities of $\mathrm{HSPH}_{\mathrm{ZZ}}$ and $\mathrm{ImmHSPH}_{\mathrm{ZZ}}$ were determined as a function of $\mathrm{pH}$ (5.0-10.0), temperature $\left(5-50{ }^{\circ} \mathrm{C}\right)$, enzymatic concentration $\left(10-50 \mathrm{mg} \mathrm{mL}^{-1}\right)$ and substrate (HSP) concentration $(0.25-2.0 \mathrm{mM})$. The enzymatic activities of the free and immobilized enzyme were determined using HSP at concentrations ranging from 0.01 to $1 \mathrm{mM}$. The corresponding $K_{\mathrm{m}}$ and $k_{\text {cat }}$ values were calculated using Hanes-Wolff plots and the Michaelis-Menten equation.

\subsection{Stability of $\operatorname{ImmHSPH}_{\mathrm{ZZ}}$}

The reusability of ImmHSPHzZ was examined by the hydrolytic activity assay under optimal conditions. At the end of each cycle, the separation of $\mathrm{ImmHSPH}_{\mathrm{ZZ}}$ from the reaction mixture was achieved by filtration and washed with $1 \mathrm{~mL}$ of $20 \mathrm{mM}$ bicarbonate buffer ( $\mathrm{pH}$ 8.5). Recovered ImmHSPH $\mathrm{ZZ}_{\mathrm{Z}}$ was then dried at room temperature for $24 \mathrm{~h}$ before use in the next cycle.

Relative activity was calculated by defining the first reaction as $100 \%$.

\subsection{SEM Assay of ImmHSPHZZ}

The ImmHSPH $\mathrm{ZZ}_{\mathrm{Z}}$ was sputtered with gold and the structures were observed using a Quanta-200 scanning electron microscope (FEI, Amsterdam, Holland).

\subsection{Statistical Analysis}

Triplicate experiments were performed for each parameter investigated and the mean and standard deviation values were reported.

\section{Conclusions}

In this study, nicotine hydroxylase from Pseudomonas sp. ZZ-5 was immobilized on Immobead 150 using covalent binding methods to optimize enzymatic production of 2,5-DHP from HSP. This preparation was characterized by SEM techniques to characterize the morphology of the immobilized enzyme on the support and the enzyme-support interaction. ImmHSPH $\mathrm{ZZ}_{\mathrm{ZZ}}$ displayed higher hydrolysis activity and catalytic performance than free $\mathrm{HSPH}_{\mathrm{ZZ}}$, and exhibited better thermal stability, storage stability, and reusability when compared with the free enzyme. Under optimal conditions, ImmHSPH $\mathrm{ZZ}$ produced $94.5 \mathrm{mg} \mathrm{L}^{-1}$ of 2,5-DHP from $200 \mathrm{mg} \mathrm{L}^{-1}$ of HSP after $30 \mathrm{~min}$ with $85.4 \%$ conversion. These results demonstrated that immobilized $\mathrm{HSPH}_{\mathrm{ZZ}}$ is a prospective system for the enzymatic production of 2,5-DHP in biotechnology applications. 
Author Contributions: C.D. designed and performed the experiments, analyzed the data and prepared the manuscript. Y.Z., H.T., Z.L., J.L., Z.Z., and S.L. performed the experiments and assisted in data analysis. D.M. and T.W. performed experiments, analyzed the data and assisted in manuscript preparation. All authors read and approved the final manuscript.

Funding: This research was funded by grants from the National Natural Science Foundation of China (21406210), Henan Province Foreign Cooperation Projects (152106000058), Program for Science \& Technology Innovation Talents in the Universities of Henan Province (18HASTIT040) and Training Plan for Young Backbone Teachers in the Universities of Henan Province (2014GJS-082).

Acknowledgments: Authors greatly acknowledge the financial support from the National Natural Science Foundation of China, Henan provincial science and technology department and Henan Provincial Department of Education.

Conflicts of Interest: The authors declare no conflicts of interest.

\section{References}

1. Benowitz, N.L. Nicotine addiction. N. Engl. J. Med. 2010, 362, 2295-2303. [CrossRef] [PubMed]

2. Hecht, S.S. Tobacco smoke carcinogens and lung cancer. J. Natl. Cancer Inst. 1999, 91, 1194-1210. [CrossRef] [PubMed]

3. Brandsch, R. Microbiology and biochemistry of nicotine degradation. Appl. Microbiol. Biotechnol. 2006, 69, 493-498. [CrossRef] [PubMed]

4. Novotny, T.E.; Zhao, F. Consumption and production waste: Another externality of tobacco use. Tob. Control 1999, 8, 75-80. [CrossRef] [PubMed]

5. Tang, H.Z.; Wang, L.J.; Wang, W.W.; Yu, H.; Zhang, K.Z.; Yao, Y.X.; Xu, P. Systematic unraveling of the unsolved pathway of nicotine degradation in Pseudomonas. PLoS Genet. 2013, 9, e1003923. [CrossRef] [PubMed]

6. Zhong, W.H.; Zhu, C.J.; Shu, M.; Sun, K.D.; Zhao, L.; Wang, C.; Ye, Z.J.; Chen, J.M. Degradation of nicotine in tobacco waste extract by newly isolated Pseudomonas sp. ZUTSKD. Bioresour. Technol. 2010, 101, 6935-6941. [CrossRef] [PubMed]

7. Ruan, A.D.; Min, H.; Zhu, W. Studies on biodegradation of nicotine by Arthrobacter sp strain HF-2. J. Environ. Sci. Health B 2006, 41, 1159-1170. [CrossRef] [PubMed]

8. Wang, M.Z.; Yang, G.Q.; Min, H.; Lv, Z.M. A novel nicotine catabolic plasmid pMH1 in Pseudomonas sp strain HF-1. Can. J. Microbiol. 2009, 55, 228-233. [CrossRef] [PubMed]

9. Qiu, J.G.; Ma, Y.; Wen, Y.Z.; Chen, L.S.; Wu, L.F.; Liu, W.P. Functional identification of two novel genes from Pseudomonas sp. strain HZN6 involved in the catabolism of nicotine. Appl. Environ. Microbiol. 2012, 78, 2154-2160. [CrossRef] [PubMed]

10. Wang, S.; Huang, H.; Xie, K.; Xu, P. Identification of nicotine biotransformation intermediates by Agrobacterium tumefaciens strain S33 suggests a novel nicotine degradation pathway. Appl. Microbiol. Biotechnol. 2012, 95, 1567-1578. [CrossRef] [PubMed]

11. Meng, X.J.; Lu, L.L.; Gu, G.F.; Xiao, M. A novel pathway for nicotine degradation by Aspergillus oryzae 112822 isolated from tobacco leaves. Res. Microbiol. 2010, 161, 626-633. [CrossRef] [PubMed]

12. Wang, M.Z.; Yang, G.Q.; Wang, X.; Yao, Y.L.; Min, H.; Lu, Z.M. Nicotine degradation by two novel bacterial isolates of Acinetobacter sp TW and Sphingomonas sp TY and their responses in the presence of neonicotinoid insecticides. World J. Microb. Microbiol. 2011, 27, 1633-1640. [CrossRef]

13. Masai, E.; Harada, K.; Peng, X.; Kitayama, H.; Katayama, Y.; Fukuda, M. Cloning and characterization of the ferulic acid catabolic genes of Sphingomonas paucimobilis SYK-6. Appl. Environ. Microbiol. 2002, 68, 4416-4424. [CrossRef] [PubMed]

14. Plaggenborg, R.; Overhage, J.; Loos, A.; Archer, J.A.; Lessard, P.; Sinskey, A.J.; Steinbuchel, A.; Priefert, H. Potential of Rhodococcus strains for biotechnological vanillin production from ferulic acid and eugenol. Appl. Environ. Microbiol. 2006, 72, 745-755. [CrossRef] [PubMed]

15. Kachalova, G.; Decker, K.; Holt, A.; Bartunik, H.D. Crystallographic snapshots of the complete reaction cycle of nicotine degradation by an amine oxidase of the monoamine oxidase (MAO) family. Proc. Natl. Acad. Sci. USA 2011, 108, 4800-4805. [CrossRef] [PubMed] 
16. Wang, S.N.; Xu, P.; Tang, H.Z.; Meng, J.; Liu, X.L.; Qing, C. “Green” route to 6-hydroxy-3-succinoyl-pyridine from (S)-nicotine of tobacco waste by whole cells of a Pseudomonas sp. Environ. Sci. Technol. 2005, 39, 6877-6880. [CrossRef] [PubMed]

17. Peng, Q.; Warloe, T.; Berg, K.; Moan, J.; Kongshaug, M.; Giercksky, K.E.; Nesland, J.M. 5-Aminolevulinic acid-based photodynamic therapy: Clinical research and future challenges. Cancer 1997, 79, 2282-2308. [CrossRef]

18. Jiang, Y.J.; Wang, Y.P.; Wang, H.; Zhou, L.Y.; Gao, J.; Zhang, Y.F.; Zhang, X.; Wang, X.M.; Li, J. Facile immobilization of enzyme on three dimensionally ordered macroporous silica via a biomimetic coating. New J. Chem. 2015, 39, 978-984. [CrossRef]

19. Alagoz, D.; Tukel, S.S.; Yildirim, D. Purification, immobilization and characterization of (R)-hydroxynitrile lyase from Prunus amygdalus turcomanica seeds and their applicability for synthesis of enantiopure cyanohydrins. J. Mol. Catal. B Enzym. 2014, 101, 40-46. [CrossRef]

20. Villeneuve, P.; Muderrhwa, J.M.; Graille, J.; Haas, M.J. Customizing lipases for biocatalysis: A survey of chemical, physical and molecular biological approaches. J. Mol. Catal. B Enzym. 2000, 9, 113-148. [CrossRef]

21. Sheldon, R.A.; Pelt, S.V. Enzyme immobilisation in biocatalysis: Why, what and how. Chem. Soc. Rev. 2013, 42, 6223-6235. [CrossRef] [PubMed]

22. Wang, F.; Nie, T.T.; Shao, L.L.; Cui, Z. Comparison of physical and covalent immobilization of lipase from Candida antarctica on polyamine microspheres of alkylamine matrix. Biocatal. Biotransform. 2014, 32, 314-326. [CrossRef]

23. Knezevic, Z.; Milosavic, N.; Bezbradica, D.; Jakovljevic, Z.; Prodanovic, R. Immobilization of lipase from Candida rugosa on Eupergit ${ }^{\circledR} \mathrm{C}$ supports by covalent attachment. Biochem. Eng. J. 2006, 30, 269-278. [CrossRef]

24. Wei, T.; Zang, J.; Zheng, Y.D.; Tang, H.Z.; Huang, S.; Mao, D.B. Characterization of a novel nicotine hydroxylase from Pseudomonas sp. ZZ-5 that catalyzes the conversion of 6-Hydroxy-3-Succinoylpyridine into 2,5-Dihydroxypyridine. Catalysts 2017, 7, 257. [CrossRef]

25. Carla, R.M.; Carolina, B.; Poppe, J.K.; Rodrigues, R.C.; Hertz, P.F.; Ayub, M.A.Z. Synthesis of butyl butyrate in batch and continuous enzymatic reactors using Thermomyces lanuginosus lipase immobilized in Immobead 150. J. Mol. Catal. B Enzym. 2016, 127, 67-75.

26. Elnashar, M.M.; Hassan, M.E.; Ghada, E.A. Grafted carrageenan gel disks and beads with polyethylenimine and glutaraldehyde for covalent immobilization of Penicillin G acylase. J. Colloid Interface Sci. 2013, 393, 27-33. [CrossRef]

27. Yuan, Y.; Luan, X.N.; Rana, X.K.; Hassan, M.E.; Dou, D.Q. Covalent immobilization of cellulase in application of biotransformation of ginsenoside Rb $\mathrm{R}_{1}$. J. Mol. Catal. B Enzym. 2016, 133, S525-S532. [CrossRef]

28. Chen, S.H.; Yen, Y.H.; Wang, C.L.; Wang, S.L. Reversible immobilization of lysozyme via coupling to reversibly soluble polymer. Enzym. Microb. Technol. 2003, 33, 643-649. [CrossRef]

29. Wei, T.; Yu, X.; Wang, Y.Y.; Zhu, Y.H.; Du, C.C.; Jia, C.X.; Mao, D.B. Purification and evaluation of the enzymatic properties of a novel fructosyltransferase from Aspergillus oryzae: A potential biocatalyst for the synthesis of sucrose 6-acetate. Biotechnol. Lett. 2014, 36, 1015-1020. [CrossRef] [PubMed]

30. Zhang, D.; Bai, S.; Ren, M.; Sun, Y. Optimization of lipase-catalyzed enantioselective esterification of ( \pm )-menthol in ionic liquid. Food Chem. 2008, 109, 72-80. [CrossRef] [PubMed]

31. Wei, T.; Feng, S.X.; Mao, D.B.; Yu, X.; Du, C.C.; Wang, X.H. Characterization of a new thermophilic and acid tolerant esterase from Thermotoga maritima capable of hydrolytic resolution of racemic ketoprofen ethyl ester. J. Mol. Catal. B Enzym. 2013, 85, 23-30.

32. Sheldon, R.A. Enzyme immobilization: The quest for optimum performance. Adv. Synth. Catal. 2007, 349, 1289-1307. [CrossRef]

33. Zhu, J.; Sun, G. Lipase immobilization on glutaraldehyde-activated nanofibrous membranes for improved enzyme stabilities and activities. React. Funct. Polym. 2012, 72, 839-845. [CrossRef]

34. Kuo, C.H.; Liu, Y.C.; Chang, C.M.J.; Chen, J.H.; Chang, C.; Shieh, C.J. Optimum conditions for lipase immobilization on chitosan-coated $\mathrm{Fe}_{3} \mathrm{O}_{4}$ nanoparticles. Carbohydr. Polym. 2012, 87, 2538-2545. [CrossRef] 
35. Milasinovic, N.; Knezevic-Jugovic, Z.; Jakovljevic, Z.; Filipovic, J.; Krusic, M.K. Synthesis of $n$-amyl isobutyrate catalyzed by Candida rugosa lipase immobilized into poly( $N$-isopropylacrylamide-co-itaconic acid) hydrogels. Chem. Eng. J. 2012, 181-182, 614-623. [CrossRef]

36. Madalozzo, A.D.; Martini, V.P.; Kuniyoshi, K.K.; de Souza, E.M.; Pedrosa, F.O.; Glogauer, A.; Zanin, G.M.; Mitchell, D.A.; Krieger, N. Immobilization of LipC12, a new lipase obtained by metagenomics, and its application in the synthesis of biodiesel esters. J. Mol. Catal. B Enzym. 2015, 116, 45-51. [CrossRef]

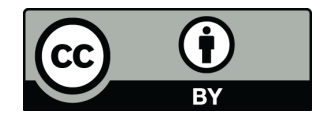

(C) 2018 by the authors. Licensee MDPI, Basel, Switzerland. This article is an open access article distributed under the terms and conditions of the Creative Commons Attribution (CC BY) license (http:/ / creativecommons.org/licenses/by/4.0/). 